\title{
The conservation ecology of North American pleurocerid and hydrobiid gastropods
}

\author{
Kenneth M. Brown ${ }^{1}$ \\ Department of Biological Sciences, Louisiana State University, Baton Rouge, Louisiana 70803 USA \\ Brian Lang ${ }^{2}$ \\ New Mexico Department of Game and Fish, One Wildlife Way, Santa Fe, New Mexico 87507 USA
}

Kathryn E. Perez ${ }^{3}$

University of North Carolina at Chapel Hill and Department of Biology, Duke University, Durham, North Carolina 27708 USA

\begin{abstract}
Many North American freshwater mollusks are at risk of extinction. Knowledge of basic ecology and systematics of the pleurocerid and hydrobiid gastropods is lacking. Pleurocerids are most diverse in southeastern USA, and we know that periphyton food limits their growth, and that their grazing, in turn, limits periphyton biomass. However, we know little about the effects of spates and current velocity on pleurocerid populations, and more work is needed to determine whether interspecific competition or significant risk from predation occurs. Hydrobiids are extremely diverse, but many species inhabit only a few springs (especially in arid western USA) and are at risk of extinction. More work is needed on their population and community ecology. Invasions pose a risk to native snail species. For example, the New Zealand mudsnail (Potamopyrgus antipodarum) interacts negatively with several hydrobiids in the Snake River in western USA. We suggest several research avenues that are needed if we are to maintain and restore pleurocerid and hydrobiid snail populations.
\end{abstract}

Key words: pleurocerids, hydrobiids, conservation, population limitation, grazing, predators, invasive species.

The high extinction risk for unionid bivalves in rivers in southeastern USA is well known (Williams et al. 1993, Neves et al. 1997). However, North American pleurocerid gastropods also are highly endangered, and their ecology and conservation have not drawn as much interest from aquatic ecologists as have the ecology and conservation of unionid bivalves (but see Stein 1976, Lydeard and Mayden 1995, Neves et al. 1997, Perez and Minton 2008). In the USA, 74\% of the Hydrobiidae and $\sim 45 \%$ of the Pleuroceridae (the 2 largest gastropod families) are considered at risk with a rank of $\leq \mathrm{G} 2$ (NatureServe 2007; Fig. 1). Elimia has experienced the greatest number of extinctions, all in river systems in Alabama and Georgia (Table 1), followed in order, by Leptoxis, Gyrotoma, and Athearnia.

\footnotetext{
${ }^{1}$ Email addresses: kmbrown@1su.edu

2 brian.lang@state.nm.us

3 keperez@duke.edu
}

A smaller number of hydrobiids have become extinct, but the fact that many species in western and southeastern USA are found at only a few isolated springs puts them at considerable risk.

Pleurocerids are limited by relatively slow adult dispersal within drainage systems and have experienced dramatic reductions in their ranges and diversity because of impoundments, nonpoint source agricultural pollution, and introduced species (Neves et al. 1997, Bogan 1998). In contrast, most pulmonate gastropods are abundant and widely distributed because of life-history adaptations, such as shorter life cycles and greater passive dispersal potential of air-breathing juveniles (Lips et al. 2003, Brown and Johnson 2004). Therefore, we will restrict our discussion to the population and community ecology of the more endangered pleurocerids and hydrobiids in North America. In particular, we discuss 


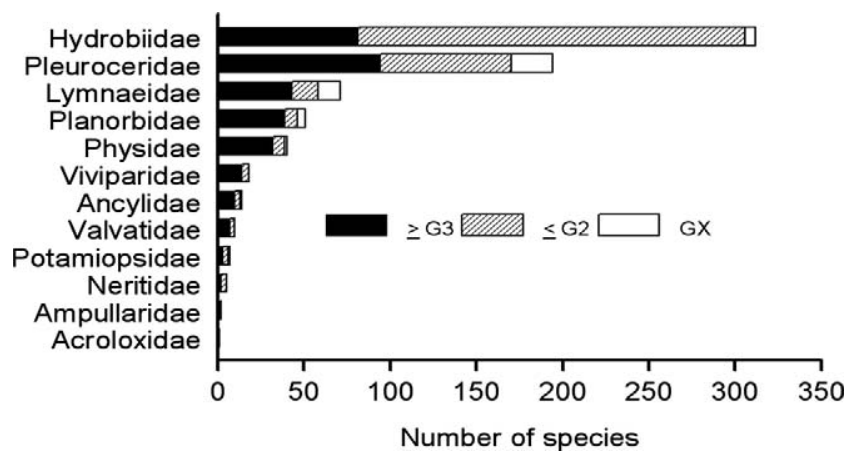

FIG. 1. Diversity and conservation status (Nature Conservancy or $\mathrm{G}$ ranks) of freshwater gastropod families. $(\geq \mathrm{G} 3=$ not at risk, $\leq \mathrm{G} 2=$ at risk, GX = extinct $)$. G-rank categories are assigned based on the number of remaining populations. Data are from NatureServe (2007), with additions by P. Johnson (Alabama Aquatic Biodiversity Center).

what factors affect pleurocerid and hydrobiid distributions and life histories and the functional role of these snails in aquatic ecosystems. We also suggest specific research avenues needed to help us better understand their ecology and improve conservation strategies.

\section{Distributions, Life Histories, and Population Ecology}

\section{Pleurocerids}

The taxonomy and systematics of the family Pleuroceridae are poorly understood and currently are based on morphological characters that might mask true species delineations (Minton and Lydeard 2003). Most of the recognized pleuocerid genera appear to be polyphyletic (Holznagel and Lydeard 2000, Minton and Lydeard 2003, Minton et al. 2005).

Pleurocerids have a distribution centered in southeastern and central USA, with greatest diversity in the watersheds draining the western and southwestern slopes of the Appalachian Mountains. Historically, diversity was highest in Alabama (100 species), followed by Tennessee (36 species), Georgia (20 species), and Kentucky (15 species) (Burch 1989). The most species-rich river system was the Coosa River in Alabama (45 species), followed by the Tennessee River ( 29 species), and the Cahaba and Cumberland rivers ( 15 species each). Other river systems in the region known for their pleurocerid diversity include the Ohio and Wabash rivers in the Midwest, the Duck and Elk rivers in Tennessee, and the Black Warrior and Flint rivers in Alabama and Georgia (Burch 1989, Brown and Johnson 2004).

Elimia is the most diverse pleurocerid genus and has $>100$ species. Elimia livescens is common in lakes and rivers ranging from Ontario and Quebec, southwest to Missouri and Texas; the other species in the genus are mostly limited to southeastern USA. The genus Gyrotoma, known for its characteristic slit in the body whorl, had 6 species in Alabama rivers, but all are now extinct (Table 1). Leptoxis (22 species) ranges from Alabama north to New England and Pennsylvania and west to Missouri and Arkansas. Lithasia (11 species) is found in 24 states, ranging from Alabama north to Pennsylvania, west to Missouri, and southwest to Arkansas and Louisiana. Io has 1 species in Tennessee and Virginia. Juga (11 species) is the only pleurocerid genus west of the continental divide and occurs in rivers in California north to Washington and British Columbia and Alberta.

Pleurocerids are perennial, with life cycles ranging from 2 to $10 \mathrm{y}$ (Richardson et al. 1988, Huryn et al. 1994, Brown and Johnson 2004). Pleurocera acuta lays eggs in late spring and early summer in small sandcovered capsules containing clutch sizes ranging from 1 to 19 eggs, whereas Elimia livescens lays single eggs that often are covered with soil (Dazo 1965). Both species mature at an age of $\sim 2 \mathrm{y}$ and can live a total of 3 to $4 \mathrm{y}$, with total fecundities estimated from 80 to 400 (Dazo 1965). Leptoxis carinata from rivers in West Virginia (Miller-Way and Way 1989) and New York (Aldridge 1982) has a biennial, semelparous

TABLE 1. Number of extinctions in pleurocerid and hydrobiid genera and their original distributions (states). Data were taken from NatureServe (2007), with additions by P. Johnson (Alabama Aquatic Biodiversity Center).

\begin{tabular}{clcl}
\hline \hline \multirow{2}{*}{ Family } & Genus & $\begin{array}{c}\text { Number of } \\
\text { extinctions }\end{array}$ & \multicolumn{1}{c}{ Original distribution } \\
\hline Pleuroceridae & Athearnia & 1 & Tennessee, Virginia \\
& Elimia & 15 & Alabama, Georgia \\
& Gyrotoma & 6 & Alabama \\
Leptoxis & 12 & Alabama, Georgia, Kentucky, Ohio, Tennessee \\
Clappia & 1 & Alabama \\
& Fluminicola & 1 & Georgia \\
& Marstonia & 1 & Alabama \\
& Pyrgulopsis & 3 & Arizona \\
\hline
\end{tabular}


life cycle. Two year olds lay eggs in late spring and early summer just before they senesce.

The most detailed recent study of life-history variation in pleurocerids involved several species of Elimia in north-central Alabama (Huryn et al. 1994). Elimia adults reproduce in early spring. Juveniles grow rapidly in their $1^{\text {st }} \mathrm{y}$ and reproduce when they reach an age of 1 or $2 \mathrm{y}$. These snails live an additional $4 \mathrm{y}$ and reproduce each year. Older snails reach a size asymptote, a characteristic that makes accurate assignment of age to individuals difficult. Life-history variation in Elimia is affected by genetic, local, and landscape-level factors (Huryn et al. 1995). Populations in streams with limestone bedrock grow throughout the year and have much higher productivity than populations in other types of streams because high groundwater percolation buffers harsh winter temperatures (Huryn et al. 1995). The populations are limited by $\mathrm{Ca}$ availability and do not occur in Ca-poor streams with sandstone substrate.

Food availability limits individual growth rates in Elimia (reviewed in Brown 2001). For example, growth of small snails increased 2-fold and growth of larger snails increased 5-fold when periphyton was increased in artificial stream channels (Hill et al. 1992). Light levels $<7 \mu \mathrm{mol} \mathrm{m}{ }^{-2} \mathrm{~s}^{-1}$ photon flux density appeared to limit periphyton and snail growth in shaded streams, and nutrient limitation occurred only at higher light intensities (Hill et al. 1992). P addition stimulates snail growth if periphyton biomass is relatively low (Stelzer and Lamberti 2002). Thus, historically, pleurocerid growth might have been limited by nutrient availability in the oligotrophic streams of southeastern USA (Stelzer and Lamberti 2002), although considerable urban development and nutrient enrichment might be occurring now (Clark et al. 2000).

Studies with Elimia indicate that periphyton production is important in regulating snail growth. However, lotic environments are stochastic, and disturbances, such as spates, frequently reset population densities to lower levels directly by washing consumers away or indirectly by reducing periphyton biomass (Statzner et al. 1988). High current velocity also might alter lotic gastropod abundances, feeding, and growth. For example, flow refugia are important for gastropods during spates. Stewart and Garcia (2002) found that densities of the pleurocerid Leptoxis increased with increasing stream substrate complexity and concluded that crevices provided refugia.

Elimia might orient upstream to minimize drag on the shell. Hydrodynamic models suggest that the shell, when held at a right angle to the current, exerts torque that causes the shell to rotate downstream and orient the animal upstream (Huryn and Denny 1997).
In comparison, juveniles congregate in faster flows because their smaller shells are less affected by flow (Huryn and Denny 1997). Johnson and Brown (1997) studied Elimia in Kentucky stream habitats that varied in shading and current velocity. Adult density and size decreased with higher flow. However, flow also reduced periphyton biomass, so the observed responses could have been caused by spate-mediated removal of larger snails, reduction of feeding rates and growth in higher flows, or the indirect effect of reduced food. Juveniles congregated in areas of high flow because they were able to use the boundary layer, where flow was substantially reduced. Considerable variation in shell anatomy occurs in pleurocerids, and the role of shell shape in the ability to withstand high flows is in need of further study.

\section{Hydrobiids}

The family Hydrobiidae is the largest family of North American freshwater mollusks (Taylor 1988, Burch 1989, Kabat and Hershler 1993). The family-level systematics of the Hydrobiidae have long been debated (Wilke et al. 2001) and are still unsettled (Hershler and Sada 2002). Therefore, we use hydrobiid as an informal collective name.

In North America, the hydrobiid genus Amnicola (8 species) is widespread and abundant in lakes and rivers and occurs in $>40$ states and across the southern provinces of Canada (Burch 1989). Somatogyrus (38 species) has a broad distribution and ranges from Florida north to Kentucky and west to Missouri. Marstonia (15 species) and Fontigens (11 species) are widely distributed in eastern North America and in southeastern Canada. The genera Birgella, Cincinattia, Lyogyrus, and Probythinella occur in south-central and southeastern Canada. The remaining 14 eastern genera are much less diverse (1-3 species each) and are limited to southeastern USA, where many species are restricted to just a few springs.

Hydrobiids, particularly the genera Pyrgulopsis (Hershler and Sada 2002) and Tryonia (Hershler 2001, Hershler et al. 2005) of the Rio Grande and Great Basin regions, have diversified extensively in western USA and northern Mexico (Hershler 1984, Taylor 1985, 1987, Hershler and Thompson 1992, Liu and Hershler 2005). The genera Colligyrus, Fluminicola, and Pristinicola also occur in British Columbia. Most western hydrobiids occur as narrow endemics tightly linked to isolated groundwater seeps, single springs, or spring complexes, and only a few genera live in larger stream ecosystems or lakes (Taylor 1987, Hershler 2001, Hershler et al. 2002a, b, Hershler and Liu 2004, Hershler et al. 2006). The biogeography of hydrobiids is largely 
explained by vicariance that reflects historic inland aquatic connections of the Rio Grande and Great Basin regions (Taylor 1985, Taylor and Bright 1987, Hershler and Thompson 1992, Hershler and Sada 2000, 2002, Liu et al. 2001, Hershler et al. 2002b, 2005). However, dispersal also has occurred by avian and human transport (Wesselingh et al. 1999, Hershler et al. 2005).

Pyrgulopsis is the largest genus of freshwater mollusks in North America (Hershler 1994, 1995, 1998). It contains 131 species (Hershler and Sada 2002, Liu and Hershler 2005) and occurs from the Pacific Coast lowlands, through the Rocky Mountains to just east of the continental divide, and in southwestern Canada (Hershler and Liu 2004, Liu and Hershler 2005). The greatest diversity of Pyrgulopsis occurs in the Great Basin (80 species; Hershler and Sada 2002). Twenty species are known from the Colorado River drainage (Hershler and Sada 2002, Hurt 2004), and 13 species are known from the Rio Grande drainage (Taylor 1987).

Tryonia (18 species; Hershler 2001), occurs in major drainages of the US Southwest and Great Basin (Taylor 1987, Hershler 1999, 2001, Hershler et al. 1999) and in the Gulf Coast and Atlantic-slope drainages of Florida (Hershler and Thompson 1987), but is absent from the Great Plains and Mississippi River drainage (Hershler 2001). One species, Tryonia imitator, lives subtidally in brackish habitats of coastal California (Kellogg 1985). Additional hydrobiids in western North America include 10 genera from the arid West (Coahulix, Cochliopa, Cochliopina, Durangonella, Eremopyrgus, Juturnia, Mexipyrgus, Mexithauma, Paludiscula, Pseudotryonia; Hershler 1984, Hershler et al. 2002a, b) and 6 genera from the Great Basin and Pacific Northwest (Amnicola, Colligyrus, Eremopyrgus, Fluminicola, Ipnobius, Pristinocola; Hershler 1999, 2001, Hershler and Liu 2004). In the arid West, hydrobiids are concentrated near spring sources, with density declining downstream (Noel 1954, Taylor 1987, Hershler 1994, 1998, Lang 2005). Springs provide thermal stability, uniform flows, and low- $\mathrm{O}_{2}$ environments (Hynes 1970), and promote high (e.g., $10^{2}-10^{5} / \mathrm{m}^{2}$ ) densities of Pyrgulopsis spp. (O'Brien and Blinn 1999, Mladenka and Minshall 2001, Martinez and Thome 2006).

Additional abiotic factors that influence the abundance and habitat use of hydrobiids include substrate size, stream shading, water velocity, and flood frequency. Pyrgulopsis bernardina chose microhabitats based on structural characteristics (coarse substrates, high vegetation density, shallow water depth, low velocity; Malcom et al. 2005). Densities of Taylorconcha serpenticola and Flumincola sp. in headwater springs of the Snake River were positively correlated with water velocity and shading from riparian canopies (Richards
2004). Hydrobiids were less susceptible to dislodgement in flows than were stream insects because hydrobiids burrowed into the sediments (Holomuzki and Biggs 2000). In New Zealand, population densities of the hydrobiid Potamopyrgus antipodarum were inversely related to flood frequency and were highest in gravel sediments where the snails burrowed to escape high flows (Holomuzki and Biggs 1999), characteristics indicating that periodic spates were important regulatory factors.

Hydrobiids are annual. Recruitment is continuous in warm springs or seasonal in cold systems (Hershler 1984, Kellogg 1985, Mladenka and Minshall 2001, Martinez and Thome 2006). Sex ratios commonly are skewed toward females (Thompson 1968). Excluding 1 parthenogen (Tryonia porrecta; Hershler et al. 2005), reproduction of native North American hydrobiids is sexual, and sexual dimorphism is pronounced (females larger than males) (Hershler 1984, Taylor 1987). Pyrgulopsis deposits egg capsules on hard substrates (Taylor 1987, Hershler 1998), and hatching occurs in $8 \mathrm{~d}$. Shell length (SL) of hatchlings is $0.3 \mathrm{~mm}$. Reproductive females vary from 0.8 to $1.24 \mathrm{~mm} \mathrm{SL}$, and males mature sexually when they reach $1.4 \mathrm{~mm}$ SL (Mladenka and Minshall 2001). Tryonia is ovoviviparous and broods a few young in the female genital duct (Hershler and Thompson 1992, Hershler et al. 2005).

\section{Functional Role in Ecosystems}

\section{Pleurocerids}

In streams in southeastern USA, pleurocerids can reduce periphyton biomass and alter production (Gregory 1983, Lamberti et al. 1989, 1995, Hill and Harvey 1990, Hill et al. 1992, Rosemond et al. 1993, Feminella and Hawkins 1995) and shift periphyton composition (Lamberti et al. 1987, Steinman et al. 1987, Tuchman and Stevenson 1991, Feminella and Hawkins 1995, reviewed in Brown 2001). In fact, gastropods can be the most abundant invertebrate grazers in southeastern US streams (Richardson et al. 1988, Hill 1992), and they affect nutrient cycling and spiraling (McCormick and Stevenson 1989). In radioisotope studies, Elimia decreased radiolabel in periphyton and the amount of dissolved organic $\mathrm{C}$ in overlying water, whereas they increased the $\mathrm{CO}_{2}$ content of overlying water through respiration and particulate organic $\mathrm{C}$ in sediment through grazing (Morales and Ward 2000a). In a dual-labeling study, Elimia fed on both algae and bacteria and showed a slight preference for algae (Morales and Ward 2000b). Stable-isotope studies suggest that Elimia consumes both periphyton and detritus (Mulholland et al. 2000), as do many other gastropods (Brown 2001). 
Periphyton abundance is regulated by nutrients (bottom-up) and snail grazing (top-down) in streams in southeastern USA. Rosemond et al. (1993) investigated the effects of nutrient addition and snail grazing on periphyton in stream channels in southeastern USA. Periphyton production increased when $\mathrm{N}$ and $\mathrm{P}$ were added to stream channels. However, periphyton production increased even more when Elimia were excluded from the stream channels, a result that indicated that snails were consuming a considerable amount of the periphyton production. Snails reduced periphyton production by $1 / 2$ in ambient nutrient conditions, and by $2 / 3$ in nutrient addition conditions.

Brown et al. (1998) manipulated monospecific and mixed populations of the pulmonate Planorbella $(=$ Helisoma $)$ trivolvis and the pleurocerid Lithasia obovata in artificial streams to determine if interspecific competition was occurring. Lithasia was a better competitor (e.g., suffered less from competition) than Planorbella (Brown et al. 1998). Field and laboratory studies of interspecific competition in 2 co-occurring species of Elimia common in Alabama streams indicated that both species were affected by competition, but neither species was competitively dominant (Cross and Benke 2002). The lack of competitive dominance might explain why these species were able to coexist (Cross and Benke 2002).

Lotic gastropods also might be important interphyletic competitors. For example, Hill (1992) argued that caddisflies and gastropods had similar diets, and experimental increases in periphyton biomass increased growth rates of both groups. In streams in northwestern USA, Juga made up $90 \%$ of the invertebrate biomass and depressed the abundance of other stream invertebrates either directly by competition for food resources or indirectly by "bulldozing" the substrate while foraging and dislodging sedentary species (Hawkins and Furnish 1987). Elimia had similar effects in southeastern US streams, where it depressed the abundances of co-occurring invertebrates (Harvey and Hill 1991).

Conventional wisdom was that the heavily armored shells of most pleurocerids reduced mortality from most predators (Vermeij and Covich 1978, Stein et al. 1984, Hawkins and Furnish 1987, reviewed in Brown 2001). Thus, in southeastern US streams, food chains involving pleurocerids were considered 2 trophic-level systems. However, darters, such as Percina shumardi, switched prey to feed on juvenile Elimia when they were abundant in spring and summer (Haag and Warren 2006). Other potential fish predators include species in the families Centrarchidae, Catostomidae, and Ictaluridae (Haag and Warren 2006). In northwestern US streams, Juga was frequently consumed by larval Pacific giant salamanders (Dicamptodon tenebrosus) in the lower

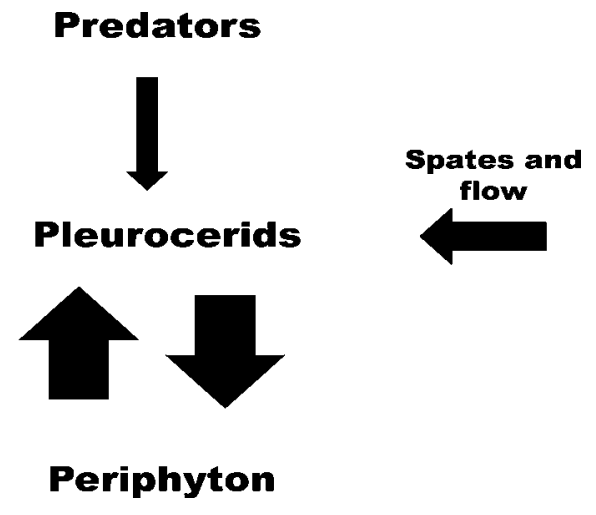

FIG. 2. Schematic model of the relative importance of topdown, bottom-up, and horizontal (competition and disturbance) factors on pleurocerid snail populations. Width of arrows reflects our best estimate of importance of each factor.

reaches of rivers (Esseltyn and Wildman 1997). Crayfish also might affect pleurocerids. Elimia livescens reared in effluent from crayfish that were fed conspecific snails underwent a shift in shell anatomy (thinner body whorls) that might deter crayfish from chipping the shell at the aperture (Krist 2002). These studies suggest that more work is needed to elucidate the potential role of predators in controlling pleurocerid populations.

We developed a simple flowchart model based on the studies discussed above to summarize the abiotic and biotic interactions that are most important for pleurocerids (Fig. 2). We propose this model, not as a definitive explanation, but to spur further experimental research. Food availability is an important determinant of pleurocerid growth, and snail grazing exerts strong limitation on periphyton. Spates and flow appear to be of intermediate importance. Interspecific competition and predation also might be important, but more research is needed to address these factors.

\section{Hydrobiids}

Hydrobiids graze on periphyton and detritus (Taylor 1987, Mladenka and Minshall 2001) and occur at high densities. Thus, community-level interactions seem possible but remain virtually unexplored. In western USA, the diversity of habitats occupied by hydrobiids might be a consequence, in part, of the absence of other groups of gill-breathing snails (i.e., viviparids, pleurocerids). Pulmonates (i.e., lymnaeids, physids) are widespread, but they occur in low abundances (Taylor 1987) and probably do not compete for food resources.

Sympatry of congeneric hydrobiids is rare (Taylor 1987, Hershler et al. 1999), but spatial habitat segregation appears to facilitate coexistence in large spring systems with greater habitat heterogeneity; 
this pattern suggests a competitive basis for substrate use (Hershler 1984). Pyrgulopsis gilae and Pyrgulopsis thermalis partition thermal habitats in hot springs. Pyrgulopsis gilae occurs in cooler waters $\left(20^{\circ} \mathrm{C}\right)$ and $P$. thermalis occurs in warmer waters $\left(38-39^{\circ} \mathrm{C}\right)$ of the principal spring flow (Taylor 1987). The apparent translocation of Tryonia circumstriata from downstream to the outflow of Diamond Y Spring might have displaced Pseudotryonia adamantina (Taylor 1987, Echelle et al. 2002). Richards and Shinn (2004) investigated competition between the native Taylorconcha serpenticola and Fluminicola sp. and the exotic New Zealand mudsnail, Potamopyrgus antipodarum, in a tributary of the Snake River, Idaho. Taylorconcha serpenticola and $P$. antipodarum occurred in patches, whereas Fluminicola was distributed randomly. Taylorconcha serpenticola and P. antipodarum competed for limited food resources but apparently were able to coexist because of niche separation. Alternatively, insufficient time might have passed since the arrival of $P$. antipodarum for competitive exclusion to have occurred.

The role of predators in controlling hydrobiid populations is relatively unknown. Some fishes (cichlids, Cyprinodon pecosensis, Gambusia affinis) are known predators of hydrobiids (Hershler 1984, Myler 2000, Johnson et al. 2007).

\section{Nonnative Gastropods}

Invasive snails affect native snails directly through competition for food and space (Cox 1999, Byers 2000, Carlsson et al. 2004) or indirectly through changes in ecosystem function or parasite populations. Thirtyseven nonnative freshwater gastropod species representing 9 families are found in North America (Table 2; NatureServe 2007). Invasions of freshwater mussels, such as the zebra mussel (Dreissena polymorpha), have been well documented because of their potential to induce large-scale ecosystem effects (Strayer et al. 1999), but much less attention has been paid to freshwater snails. This lack of attention is notable even though invasive apple snails (Pomacea spp.) and Potamopyrgus antipodarum have damaged endangered species (Cox 1999, Byers 2000, Richards and Shinn 2004), ecological communities (Bowler 1991), ecosystems (Hall et al. 2003, Carlsson et al. 2004), and crops, such as rice and taro (Estebenet 1995).

The best-studied invasive freshwater gastropod in North America is P. antipodarum. This species originated in New Zealand (Winterbourn 1970) and has spread to Australia (Ponder 1988), Europe (Hubendick 1950), and North America (Bowler 1991). In the 1980s, it became established in the midreaches of the Snake River, Idaho (Taylor 1987, Bowler 1991), where it became the predominant macroinvertebrate (Bowler 1991). It can reach densities up to $800,000 / \mathrm{m}^{2}$ (Dorgelo 1987). The species has now been reported from California, Washington, Oregon, Utah, Arizona, Colorado, Wyoming, and Montana in western North America and from Lakes Ontario, Erie, and Superior in eastern North America (Grigorovich et al. 2003, Levri et al. 2007).

Potamopyrgus antipodarum reproduces by parthenogenesis (Dybdahl and Lively 1998) and is a perennial, live-bearing snail with a high reproductive potential (Zaranko et al. 1997). As in other hydrobiids, an operculum seals the shell and enables the individual to survive short-term desiccation and exposure, including passage through a fish's digestive system (Haynes et al. 1985). Potamopyrgus antipodarum often is found in stream drift and, even when attached to a substrate, moves quickly (up to $1 \mathrm{~m} / \mathrm{h}$; Richards et al. 2001). The species is found in a wide range of habitats, including rivers, reservoirs, lakes, and estuaries (Jacobson and Forbes 1997, Collier and Winterbourn 2000). It grazes on periphyton and decaying plant and animal material (Haynes and Taylor 1984) and quickly colonizes newly exposed habitat where it is more able to exploit early successional periphyton communities than are native snails (Schreiber et al. 2003, Richards and Shinn 2004).

Potamopyrgus antipodarum populations have some of the highest secondary production values ever recorded (Hall et al. 2006). The species consumes up to $93 \%$ of primary production in streams (Hall et al. 2003, Riley 2003) and alters energy flow (Ryan 1982, McCarter 1986, Cada 2004, Hall et al. 2006). Thus, it might sequester $C$, thereby changing food webs at the expense of native species. For example, Richards (2004) found that populations of the endangered hydrobiid $T$. serpenticola were negatively affected by P. antipodarum. Last, $P$. antipodarum has depressed the abundance of other macroinvertebrates in western US rivers by physical displacement (Kerans et al. 2005).

\section{Suggested Research}

Successful conservation of extant populations, propagation of at-risk species, and reintroduction of locally extirpated species to stream and spring systems will require more basic research on the life histories and ecology of pleurocerids and hydrobiids. Here, we suggest some specific research questions and avenues that merit attention.

For pleurocerids, we need more detailed studies of life histories and mechanisms that determine population densities and distributions of genera other than Elimia. For example, little is known of reproductive patterns and longevities for genera such as Lithasia, Leptoxis, Pleurocera, and Io, particularly in rivers in 
TABLE 2. Alien freshwater gastropods in North America; [native] indicates a species is native in parts of North America but introduced into other parts of the continent. For these species, states and provinces listed are those where it has been introduced by humans. Data were taken from NatureServe (2007).

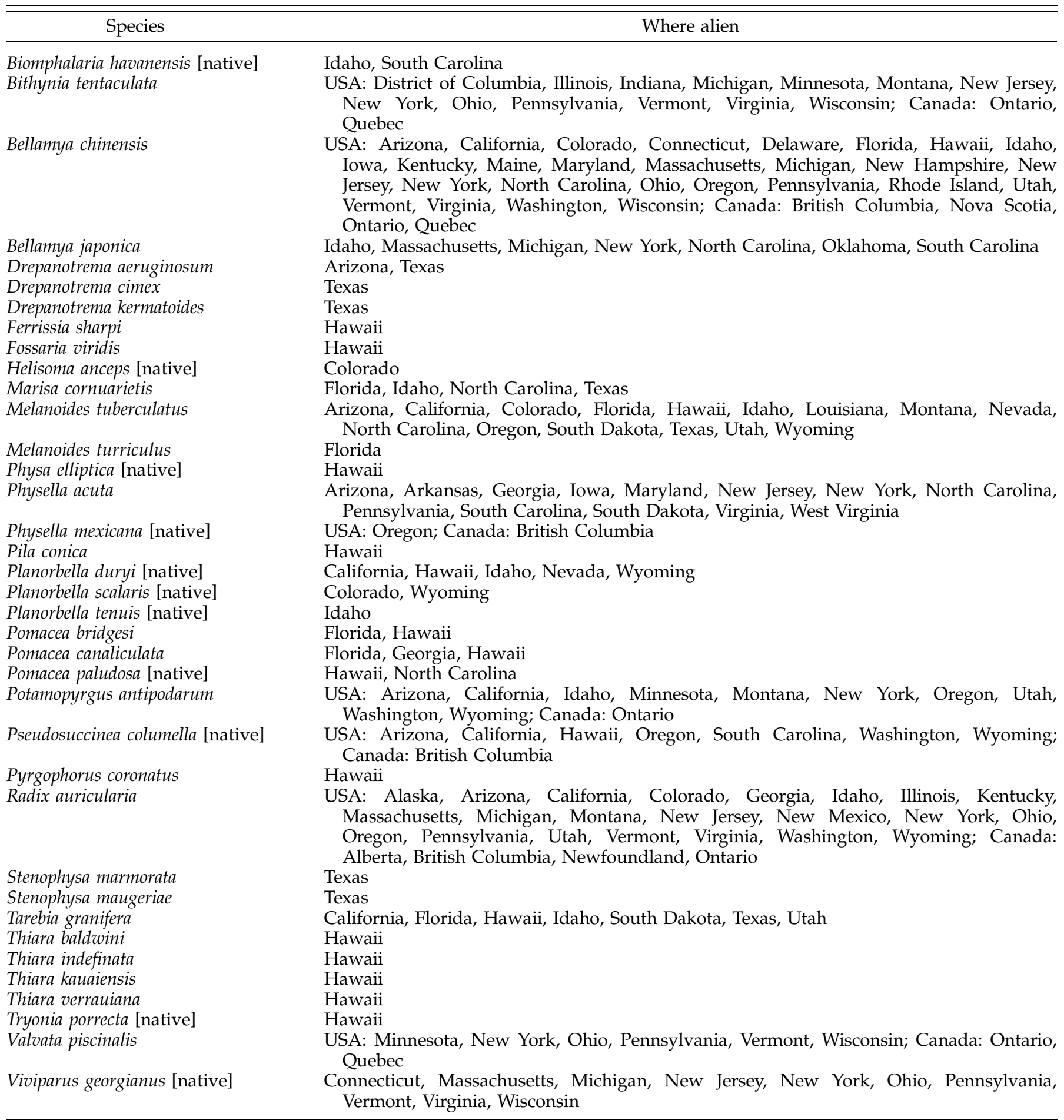

Tennessee and Alabama where they are more diverse than elsewhere. More information also is needed on how physicochemical factors might affect pleurocerid abundances and distributions. These studies would provide the necessary background for successful propagation and reintroduction of at-risk species. Moreover, research is needed to develop successful propagation and reintroduction techniques. Studies 
that assess the relative roles and interactions of periphyton abundance and spates in determining snail population dynamics would be particularly valuable. Experimental studies are needed to determine whether genera of pleurocerids other than Elimia limit periphyton production and composition, as are additional studies of interspecific competition between co-occurring genera of pleurocerids in rivers where pleurocerid assemblages are diverse. We are beginning to understand that predators, such as fish and crayfish, can affect, at least, juvenile pleurocerids, but predator manipulations are needed to test this hypothesis.

Hydrobiids are difficult to identify, and future studies should combine information from molecular markers, functional protein markers, shell morphology, and soft anatomy to aid in identification. Biogeographic studies would benefit from: 1) combined studies of drainage patterns and spatiotemporal analyses of geophysical factors that influence formation of spring habitats, and 2) innovative approaches to extract a phylogenetic signal from fossil shells (e.g., stable-isotope assays; Hershler et al. 1999, Hershler and Sada 2002). Surveys should be done with standardized sampling protocols to determine distributions, species composition, and status of hydrobiid populations. Alpha-diversity surveys and DNA barcoding (Hebert et al. 2003) could be used to identify cryptic species (Pfenninger and Schwenk 2007). Studies are needed that address life history, feeding ecology, population dynamics, and habitat requirements of hydrobiids relative to environmental factors, such as stream-flow modifications and groundwater withdrawals, altered physicochemical environments, contaminants, and riparian disturbances. Studies are needed of interactions between hydrobiids and other aquatic animals and of the roles of hydrobiids in nutrient cycling and energy flow.

We need a better understanding of the roles of invasive species. Research should address how invaders interact with native communities, especially whether they compete directly with native organisms for resources or affect natives indirectly by altering parasite communities. Research also is needed on mechanisms to control the spread of invasive snails.

Artificial propagation and reintroduction techniques have not been perfected, and more work is needed to assess the risks of controlled propagation and to develop genetic management guidelines like those for freshwater mussels for at-risk gastropods (Jones et al. 2006). Further collaboration is needed among geneticists, taxonomists, and agency staff to develop guidelines for use of genetic data when deciding whether at-risk species, subspecies, and unique population units of pleurocerids and hydro- biids merit protection under state and federal laws (Fallon 2007, Perez and Minton 2008).

\section{Acknowledgements}

The authors thank Steve Lysne, Russell L. Minton, and Jeffrey Sides for their contributions to the Freshwater Mollusk Conservation Society gastropod symposium, and Alan Christian, John Harris, Caryn Vaughn, and Dave Strayer for organizing and editing this special issue. Russell L. Minton assembled the table of invasive species and localities. KEP is supported by the Seeding Postdoctoral Innovators in Research and Education fellowship (SPIRE) program at University of North Carolina-Chapel Hill, funded through the Minority Opportunities in Research Division of the National Institute of General Medical Sciences (GM00678) and the laboratory of Cliff Cunningham and the Department of Biological Sciences at Duke University.

\section{Literature Cited}

Aldridge, D. W. 1982. Reproductive tactics in relation to lifecycle bioenergetics in three natural populations of the freshwater snail Leptoxis carinata. Ecology 63:196-208.

BogAN, A. E. 1998. Freshwater molluscan conservation in North America: problems and practices. Journal of Conchology, Special Publication 2:223-230.

BOWLER, P. A. 1991. The rapid spread of the freshwater hydrobiid snail Potamopyrgus antipodarum (Gray) in the Middle Snake River, southern Idaho. Proceedings of the Desert Fishes Council 21:173-182.

Brown, K. M. 2001. Mollusca: Gastropoda. Pages 297-325 in J. H. Thorp and A. P. Covich (editors). Ecology and classification of North American freshwater invertebrates. $2^{\text {nd }}$ edition. Academic Press, Orlando, Florida.

Brown, K. M., J. E. Alexander, And J. H. Thorp. 1998. Differences in the ecology and distribution of lotic pulmonate and prosobranch gastropods. American Malacological Bulletin 14:91-101.

Brown, K. M., AND P. D. Johnson. 2004. Comparative conservation ecology of pleurocerid and pulmonate gastropods of the United States. American Malacological Bulletin 19:57-62.

Burch, J. B. 1989. North American freshwater snails. Malacological Publications, Hamburg, Michigan.

BYERS, J. E. 2000. Competition between two estuarine snails: implications for invasions of exotic species. Ecology 81: 1225-1239.

CADA, C. 2004. Interactions between the invasive New Zealand mud snail, Potamopyrgus antipodarum, baetid mayflies, and fish predators. MS Thesis, Montana State University, Bozeman, Montana.

Carlsson, N. O. L., C. Brönmark, and L. A. Hansson. 2004. Invading herbivory: the Golden Apple Snail alters ecosystem functioning in Asian wetlands. Ecology 85: 1575-1580.

Clark, G. M., D. K. Mueller, and M. A. Mast. 2000. Nutrient 
concentrations and yields in undeveloped stream basins of the United States. Journal of the American Water Resources Association 36:849-860.

Collier, K. J., AND M. J. Winterbourn. 2000. New Zealand stream invertebrates: ecology and implications for management. New Zealand Limnological Society, Christchurch, New Zealand.

Cox, G. W. 1999. Alien species in North American and Hawaii. Island Press, Washington, DC.

Cross, W. F., AND A. C. BenKe. 2002. Intra-and interspecific competition among coexisting lotic snails. Oikos 96:251264.

DAzo, B. C. 1965. The morphology and natural history of Pleurocera acuta and Goniobasis livescens (Gastropoda: Cerithiacea: Pleuroceridae). Malacologia 2:1-80.

Dorgelo, J. 1987. Density fluctuations in populations (19821986) and biological observations of Potamopyrgus jenkinsi in two trophically differing lakes. Hydrobiological Bulletin 21:95-110.

DybDahl, M. F., AND C. M. Lively. 1998. Host-parasite coevolution: evidence for rare advantage and time-lagged selection in a natural population. Evolution 52:10571066.

Echelle, A. A., A. F. Echelle, AND L. Kiner. 2002. Monitoring effects of a renovation project on endangered fish and invertebrates in Diamond Y Draw. Final report to the Texas Parks and Wildlife Department and the US Fish and Wildlife Service. (Available from: Texas Parks and Wildlife Department, 4200 Smith School Road, Austin, Texas 78744 USA.)

Esseltyn, J. A., AND R. C. Wildman. 1997. Observations of Juga in the diet of larval Pacific giant salamanders (Dicamptodon tenebrosus). Northwestern Naturalist 78:70-73.

Estebenet, A. L. 1995. Food and feeding in Pomacea canaliculata (Gastropoda: Ampullariidae). Veliger 38:277-283.

FaLLON, S. M. 2007. Genetic data and the listing of species under the U.S. Endangered Species Act. Conservation Biology 21:1186-1195.

Feminella, J. W., and C. P. Hawkins. 1995. Interactions between stream herbivores and periphyton: a quantitative analysis of past experiments. Journal of the North American Benthological Society 14:465-509.

Gregory, S. V. 1983. Plant-herbivore interactions in stream systems. Pages 157-189 in J. R. Barnes and G. W. Minshall (editors). Stream ecology. Plenum Press, New York.

Grigorovich, I. A., A. V. Korniushin, D. K. Gray, I. C. Duggan, I. R. Colautti, and H. J. MacIsaAc. 2003. Lake Superior: an invasion coldspot? Hydrobiologia 499:191-210.

HaAG, W. R., AND M. L. WARREN. 2006. Seasonal feeding specialization on snails by river darters (Percina shumardi) with a review of snail feeding by other darter species. Copeia 2006:604-612.

Hall, R. O., M. F. Dybdahl, and M. C. VanderLoop. 2006. Extremely high secondary production of introduced snails in rivers. Ecological Applications 16:1121-1131.

Hall, R. O., J. L. TANK, AND M. F. DybDahl. 2003. Exotic snails dominate nitrogen and carbon cycling in a highly productive stream. Frontiers in Ecology and the Environment 1:407-411.

Harvey, B. C., AND W. R. Hill. 1991. Effects of snails and fish on benthic invertebrate assemblages in a headwater stream. Journal of the North American Benthological Society 10:263-270.

Hawkins, C. P., AND J. K. Furnish. 1987. Are snails important competitors in stream ecosystems? Oikos 49:209-220.

Haynes, A., AND B. J. R. TAYlor. 1984. Food finding and food preference in Potamopyrgus jenkinsi (E. A. Smith) (Gastropoda: Prosobranchia). Archiv für Hydrobiologie 100: 479-491.

Haynes, A., B. J. R. TAYlor, And M. E. VArley. 1985. The influence of the mobility of Potamopyrgus jenkinsi (Smith E. A.) (Prosobranchia: Hydrobiidae) on its spread. Archiv für Hydrobiologie 103:497-508.

Hebert, P. D. N., A. CYwinski, S. L. Ball, AND J. R. DeWaARd. 2003. Biological identifications through DNA barcodes. Proceedings of the Royal Society of London Series BBiological Sciences 270:313-321.

Hershler, R. 1984. The hydrobiid snails (Gastropoda: Rissoacea) of the Cuatro Ciénegas Basin: systematic relationships and ecology of a unique fauna. Journal of the Arizona-Nevada Academy of Science 19:61-76.

Hershler, R. 1994. A review of the North American freshwater snail genus Pyrgulopsis (Hydrobiidae). Smithsonian Contributions to Zoology 555:1-115.

Hershler, R. 1995. New freshwater snails of the genus Pyrgulopsis (Rissooidea: Hydrobiidae) from California. Veliger 38:343-373.

Hershler, R. 1998. A systematic review of the hydrobiid snails (Gastropoda: Rissooidea) of the Great Basin, western United States. Part I. Genus Pyrgulopsis. Veliger 41:1-132.

HershleR, R. 1999. A systematic review of the hydrobiid snails (Gastropoda: Rissooidea) of the Great Basin, western United States. Part II. Genera Colligyrus, Eremopyrgus, Fluminicola, Pristinocola, and Tryonia. Veliger 42:306-337.

Hershler, R. 2001. Systematics of the North and Central American aquatic snail genus Tryonia (Rissooidea: Hydrobiidae). Smithsonian Contributions to Zoology 612:1-52.

Hershler, R., AND H.-P. LiU. 2004. A molecular phylogeny of aquatic gastropods provides a new perspective on biogeographic history of the Snake River region. Molecular Phylogenetics and Evolution 32:927-937.

Hershler, R., H.-P. Liu, T. J. Frest, E. J. Johannes, and W. H. Clark. 2006. Genetic structure of the western North American gastropod genus Taylorchoncha and description of a second species. Journal of Molluscan Studies 72:167177.

Hershler, R., H.-P. Liu, AND J. J. LANDye. 2002a. A new species of Eremopyrgus (Hydrobiidae: Cochliopinae) from the Chihuahuan Desert, Mexico. Journal of Molluscan Studies 68:7-15.

Hershler, R., H.-P. Liu, And C. A. Stockwell. 2002b. A new genus and species of aquatic gastropod (Risooidea: Hydrobiidae) from the North American Southwest: 
phylogenetic relationships and biogeography. Proceedings of the Biological Society of Washington 115:171-188.

Hershler, R., R. M. Mulvey, and H.-P. Liu. 1999. Biogeography in the Death Valley Region: evidence from springsnails (Hydrobiidae: Tryonia). Zoological Journal of the Linnean Society 126:335-354.

Hershler, R., R. M. Mulvey, and H.-P. Liu. 2005. Genetic variation in the Desert Springsnail (Tryonia porrecta): implication for reproductive mode and dispersal. Molecular Ecology 14:1755-1765.

Hershler, R., AND D. W. SAdA. 2000. A new species of hydrobiid snail of the genus Pyrgulopsis from northwestern Nevada. Veliger 43:367-375.

Hershler, R., AND D. W. SADA. 2002. Biogeography of Great Basin aquatic snails of the genus Pyrgulopsis. Pages 255276 in R. Hershler, D. B. Madsen, and D. R. Currey (editors). Great Basin aquatic systems history. Smithsonian Contributions to Earth Sciences 33. Smithsonian Institution, Washington, DC.

Hershler, R., and F. G. Thompson. 1987. North American Hydrobiidae (Gastropoda: Rissoacea): redescription and systematic relationships of Tryonia Simpson 1865 and Pyrgulopsis Call and Pilsbry 1886. Nautilus 101:25-32.

Hershler, R., and F. G. Thompson. 1992. A review of the aquatic gastropod subfamily Cochliopinae (Prosobranchia: Hydrobiidae). Malacological Review Supplement 5: $1-140$.

HiLl, W. R. 1992. Food limitation and interspecific competition in snail-dominated streams. Canadian Journal of Fisheries and Aquatic Sciences 49:1257-1267.

Hill, W. R., and B. C. Harvey. 1990. Periphyton responses to higher trophic levels and light in a shaded stream. Canadian Journal of Fisheries and Aquatic Sciences 47: 2307-2314.

Hill, W. R., S. C. Weber, and A. J. Stewart. 1992. Food limitation of two lotic grazers: quantity, quality, and size specificity. Journal of the North American Benthological Society 11:420-432.

HolomuzKI, J. R., AND B. J. F. BigGs. 1999. Distributional responses to flow disturbance by a stream dwelling snail. Oikos 87:36-47.

HolomuzKI, J. R., And B. J. F. Biggs. 2000. Taxon-specific responses to high flow disturbance in streams: implications for population persistence. Journal of the North American Benthological Society 19:670-679.

Holznagel, W. E., AND C. Lydeard. 2000. A molecular phylogeny of North American Pleuroceridae (Gastropoda: Cerithioidea) based on mitochondrial and DNA sequences. Journal of Molluscan Studies 66:233-257.

HubeNDick, B. 1950. The effectiveness of passive dispersal in Hydrobia jenkinisi. Zoologiska Bidrag från Uppsala 28: 493-504.

HuRT, C. R. 2004. Genetic divergence, population structure and historical demography of rare Springsnails (Pyrgulopsis) in the lower Colorado River basin. Molecular Ecology 13:1173-1187.

Huryn, A. D., A. C. BenKe, And G. M. Ward. 1995. Direct and indirect effects of geology on the distribution, biomass, and production of the freshwater snail Elimia. Journal of the North American Benthological Society 14:519-534.

Huryn, A. D., AND M. W. Denny. 1997. A biomechanical hypothesis explaining upstream movements by the freshwater snail Elimia. Functional Ecology 11:472-483.

Huryn, A. D., J. Koebel, And A. C. Benke. 1994. Life history and longevity of the pleurocerid snail Elimia: a comparative study of eight populations. Journal of the North American Benthological Society 13:540-556.

Hynes, H. B. N. 1970. The ecology of running waters. University of Toronto Press, Toronto, Ontario.

JACOBSON, R., AND V. E. Forbes. 1997. Clonal variation in lifehistory traits and feeding rates in the gastropod, Potamopyrgus antipodarum: performance across a salinity gradient. Functional Ecology 11:260-267.

Johnson, P. D., AND K. M. BROWN. 1997. The role of current and light in explaining the habitat distribution of the lotic snail Elimia semicarinata. Journal of the North American Benthological Society 15:344-369.

Johnson, S. G., C. D. Hulsey, and F. J. García de León. 2007. Spatial mosaic evolution of snail defensive traits. BioMed Central Evolutionary Biology 7:50. doi:10.1186/ 1471-2148-7-50.

Jones, J. W., E. M. Hallerman, and R. J. Neves. 2006. Genetic management guidelines for captive propagation of freshwater mussels (Unionoidea). Journal of Shellfish Research 25:527-535.

Kabat, A. R., and R. Hershler. 1993. The prosobranch snail family Hydrobiidae (Gastropoda: Rissooidea): review of classification and supraspecific taxa. Smithsonian Contributions to Zoology 547:1-94.

KellogG, M. G. 1985. Contributions to our knowledge of Tryonia imitator (Pilsbry, 1899). MS Thesis, San Francisco State University, San Francisco, California.

Kerans, B. L., M. F. Dybdahl, M. M. Gangloff, and J. E. JANNOT. 2005. Macroinvertebrate assemblages and the New Zealand mud snail, a recent invader to streams of the Greater Yellowstone ecosystem. Journal of the North American Benthological Society 24:123-138.

KRIST, A. C. 2002. Crayfish induce a defensive shell shape in a freshwater snail. Invertebrate Zoology 121:235-242.

Lamberti, G. H., L. R. Ashkenas, S. V. Gregory, and A. D. STEINMAN. 1987. Effects of three herbivores on periphyton communities in laboratory streams. Journal of the North American Benthological Society 6:92-104.

Lamberti, G. H., S. V. Gregory, L. R. Ashrenas, J. L. Li, A. D. SteinMAN, AND C. D. MCINTIRE. 1995. Influence of grazer type and abundance on plant-herbivore interactions in streams. Hydrobiologia 306:179-186.

Lamberti, G. H., S. V. Gregory, L. R. Ashrenas, A. D. Steinman, AND C. D. McIntiRe. 1989. Productive capacity of periphyton as a determinant of plant-herbivore interactions in streams. Ecology 70:1840-1856.

LANG, B. K. 2005. Longitudinal distribution and abundance of the Alamosa springsnail, Pseudotryonia alamosae, in the Alamosa Creek drainage, Socorro County, New Mexico. Final report to the U.S. Fish and Wildlife Service. New Mexico Department of Game and Fish, Albuquerque, New Mexico. (Available from: New Mexico Department 
of Game and Fish, One Wildlife Way, Santa Fe, New Mexico 87507 USA.)

Levri, E. P., A. A. Kelly, And E. Love. 2007. The invasive New Zealand mud snail (Potamopyrgus antipodarum) in Lake Erie. Journal of Great Lakes Research 33:1-6.

Lips, K. R., J. D. Reeve, And L. R. Witters. 2003. Ecological traits predicting amphibian population declines in Central America. Conservation Biology 17:1078-1088.

LiU, H.-P., AND R. Hershler. 2005. Molecular systematics and radiation of western North American nymphophiline gastropods. Molecular Phylogenetics and Evolution 34: 284-298.

Liu, H.-P., R. Hershler, And F. G. Thompson. 2001. Phylogenetic relationships of the Cochliopinae (Rissooidea: Hydrobiidae): an enigmatic group of aquatic gastropods. Molecular Phylogenetics and Evolution 21:17-25.

LydeARD, C., AND R. L. MAYDEN. 1995. A diverse and endangered aquatic ecosystem of the southeast United States. Conservation Biology 9:800-805.

Malcom, J., W. R. RadKe, and B. K. Lang. 2005. Habitat associations of the San Bernardino Springsnail, Pyrgulopsis bernardina (Hydrobiidae). Journal of Freshwater Ecology 20:71-77.

Martinez, M. M., and D. M. Thome. 2006. Habitat usage by the Page springsnail, Pyrgulopsis morrisoni (Gastropoda: Hydrobiidae), from central Arizona. Veliger 18:8-16.

MCCARTER, N. H. 1986. Food and energy in the diet of brown and rainbow trout from Lake Benmore, New Zealand. New Zealand Journal of Marine and Freshwater Research 20:551-559.

McCormick, P. M., And R. J. Stevenson. 1989. Effects of snail grazing on benthic algal community structure in different nutrient environments. Journal of the North American Benthological Society 8:162-172.

Miller-WAy, C. A., AND C. M. WAy. 1989. The life history of Leptoxis dilatata (Conrad) (Prosobranchia: Pleuroceridae) from the Laurel Fork River, West Virginia. American Midland Naturalist 122:193-198.

Minton, R. L., AND C. LydEARD. 2003. Phylogeny, taxonomy, genetics and global heritage ranks of an imperiled, freshwater snail genus Lithasia (Pleuroceridae). Molecular Ecology 12:75-87.

Minton, R. L., S. P. Savarese, And D. C. CAmpbell. 2005. A new species of "Lithasia" (Mollusca: Caenogastropoda: Pleuroceridae) from the Harpeth River, Tennessee, U.S.A. Zootaxa 1054:31-42.

MladenKa, G. C., And G. W. Minshall. 2001. Variation in the life history and abundance of three populations of Bruneau hot springsnails (Pyrgulopsis bruneauensis). Western North American Naturalist 61:204-212.

MorAlES, J. B. T., AND A. K. WARD. 2000a. Snail grazers affect the fate of labile dissolved organic $C$ in streams. Journal of the North American Benthological Society 19:659-669.

Morales, J. B. T., AND A. K. WARD. 2000b. Differential incorporation of algae and bacteria by Elimia clara (Prosobranchia: Pleuroceridae)—a study using duallabeled periphyton. Journal of the North American Benthological Society 19:289-297.

Mulholland, P. J., J. L. TAnK, D. M. SAnzone, W. M.
Wollheim, B. J. Peterson, J. R. Webster, and J. L. Meyer. 2000. Food resources of stream macroinvertebrates determined by natural-abundance stable $\mathrm{C}$ and $\mathrm{N}$ isotopes and a $15 \mathrm{~N}$ tracer addition. Journal of the North American Benthological Society 19:145-157.

MyleR, C. D. 2000. Habitat improvement for an endangered springsnail in southwest Idaho. MS Thesis, Idaho State University, Boise, Idaho.

NATURESERVE. 2007. NatureServe explorer: an online encyclopedia of life [web application]. Version 6.1. NatureServe, Arlington, Virginia. (Available from: http://www. natureserve.org/explorer)

Neves, R. J., A. E. Bogan, J. D. Williams, S. A. Ahlstedt, and P. W. HARTFiELD. 1997. Status of aquatic mollusks in the Southeastern United States: a downward spiral of diversity. Pages 43-86 in G. W. Benz and D. E. Collins (editors). Aquatic fauna in peril, the southeastern perspective. Southeast Aquatic Research Institute Special Publication 1. Lenz Design and Communications, Decatur, Georgia.

Noel, M. S. 1954. Animal ecology of a New Mexico springbrook. Hydrobiologia 6:120-135.

O'BRIEN, C., AND D. W. BLINN. 1999. The endemic spring snail Pyrgulopsis montezumensis in a high $\mathrm{CO}_{2}$ environment: importance of extreme chemical habitats as refugia. Freshwater Biology 42:225-234.

Perez, K. E., And R. L. Minton. 2008. What's in a name? Practical applications of systematics and taxonomy in freshwater gastropod conservation: a review. Journal of the North American Benthological Society 27:471-483.

Pfenninger, M., And K. Schwenk. 2007. Cryptic animal species are homogeneously distributed among taxa and biogeographical regions. BioMed Central Evolutionary Biology 7:121-126.

PONDER, W. F. 1988. Potamopyrgus antipodarum, a molluscan colonizer of Europe and Australia. Journal of Molluscan Studies 4:271-286.

Richards, D. C. 2004. Competition between the threatened Bliss Rapids snail Taylorconcha serpenticola (Hershler et al.) and the invasive, aquatic snail, Potamopyrgus antipodarum (Gray). PhD Dissertation, Montana State University, Bozeman, Montana.

Richards, D. C., L. D. CAZIER, AND G. T. Lester. 2001. Spatial distribution of three snail species, including the invader Potamopyrgus antipodarum in a freshwater spring. Western North American Naturalist 61:375-380.

Richards, D. C., AND D. C. SHINN. 2004. Intraspecific competition and development of size structure in the invasive snail Potamopyrgus antipodarum (Gray, 1853). American Malacological Bulletin 19:33-37.

Richardson, T. D., J. F. Scheiring, AND K. M. Brown. 1988. Secondary production of two lotic snails (Pleuroceridae: Elimia). Journal of the North American Benthological Society 7:234-241.

RILEY, L. A. 2003. Exotic species impact: exploitative competition between stream snails? MS Thesis, Washington State University, Pullman, Washington.

Rosemond, A. D., P. J. Mulholland, AND J. W. Elwood. 1993. Top-down and bottom-up control of stream periphyton: 
effects of nutrients and herbivores. Ecology 74:12641280.

RYAN, P. A. 1982. Energy contents of some New Zealand freshwater animals. New Zealand Journal of Marine and Freshwater Research 16:283-287.

Schreiber, E. S. G., G. P. QuinN, and P. S. Lake. 2003. Distribution of an alien aquatic snail in relation to flow variability, human activities and water quality. Freshwater Biology 48:951-961.

Statzner, B., J. A. Gore, and V. H. Resh. 1988. Hydraulic stream ecology: observed patterns and potential applications. Journal of the North American Benthological Society 7:307-360.

Stelzer, R. S., And G. A. Lamberti. 2002. Ecological stoichiometry in running waters: periphyton chemical composition and snail growth. Ecology 83:1039-1051.

Stein, C. B. 1976. Gastropods. Pages 21-41 in H. Boschung (editor). Endangered and threatened species of Alabama. Bulletin of the University of Alabama Museum of Natural History 2. University of Alabama Museum of Natural History, Tuscaloosa, Alabama.

Stein, R. A., C. G. Goodman, and E. A. Marschall. 1984. Using time and energetic measures of cost in estimating prey value for fish predators. Ecology 65:702-715.

Steinman, A. D., C. D. McIntire, S. V. Gregory, G. H. Lamberti, AND L. R. AshKenAs. 1987. Effects of herbivore type and density on taxonomic structure and physiognomy of algal assemblages in laboratory streams. Journal of the North American Benthological Society 6:175-186.

SteWART, T. W., AND J. E. GARCIA. 2002. Environmental factors causing local variation in density and biomass of the snail Leptoxis carinata in Fishpond Creek, Virginia. American Midland Naturalist 148:172-180.

Strayer, D. L., N. F. Caraco, J. J. Cole, S. Findlay, and M. L. PACE. 1999. Transformation of freshwater ecosystems by bivalves. BioScience 49:19-27.

TAYLOR, D. W. 1985. Evolution of freshwater drainages and molluscs in western North America. Pages 239-321 in C. J. Smiley (editor). Late Cenozoic history of the Pacific Northwest. American Academy of Sciences Pacific Division, San Francisco, California.

TAYLOR, D. W. 1987. Fresh-water mollusks from New Mexico and vicinity. New Mexico Bureau of Mines and Mineral Resources Bulletin 116:1-50.

TAYLOR, D. W. 1988. Aspects of freshwater mollusk ecological biogeography. Palaeogeography, Palaeoclimatology, and Palaeoecology 62:511-576.

TAYLOR, D. W., AND R. C. BRIGHT. 1987. Drainage history of the Bonneville Basin. Utah Geological Association Publication 16:239-256.

Thompson, F. G. 1968. The aquatic snails of the family Hydrobiidae of peninsular Florida. University of Florida Press, Gainesville, Florida.

Tuchman, N. C., and R. J. Stevenson. 1991. Effects of selective grazing by snails on benthic algal succession. Journal of the North American Benthological Society 10:430-443.

VermeIJ, G. J., AND A. P. Covich. 1978. Coevolution of freshwater gastropods and their predators. American Naturalist 112:833-843.

Wesselingh, F. P., G. D. CAdÉE, And R. Renema. 1999. Flying high: on the airborne dispersal of aquatic organisms as illustrated by the distribution histories of the gastropod genera Tryonia and Planorbarius. Geologie en Mijnbouw 78:165-174.

Wilke, T. E., G. M. Davis, A. FAlniowski, F. GiUsti, And M. Bodon. 2001. Molecular systematics of Hydrobiidae (Mollusca: Gastropoda: Rissooidea): testing monophyly and phylogenetic relationships. Proceedings of the Academy of Natural Sciences of Philadelphia 151:1-21.

Williams, J. D., M. L. Warren, K. S. Cummings, L. L. Harris, AND R. J. Neves. 1993. Conservation status of freshwater mussels of the United States and Canada. Fisheries 18(9):6-22.

Winterbourn, M. J. 1970. The New Zealand species of Potamopyrgus (Gastropoda: Hydrobiidae). Malacologia 10:283-321.

Zaranko, D. T., D. G. Farara, and F. G. Thompson. 1997. Another exotic mollusc in the Laurentian Great Lakes: the New Zealand native Potamopyrgus antipodarum (Gray, 1843) (Gastropoda, Hydrobiidae). Canadian Journal of Fisheries and Aquatic Sciences 54:809-814.

Received: 22 June 2007 Accepted: 12 December 2007 